\title{
How to communicate with farmers about climate change: Farmers' perceptions and adaptations to increasingly variable weather patterns in Maine (USA)
}

John M. Jemison, Jr., ${ }^{a} *$ Damon Hall, ${ }^{\mathrm{a}, \mathrm{b}}$ Stephanie Welcomer, ${ }^{\mathrm{c}}$ and Jane Haskell ${ }^{\mathrm{d}}$ University of Maine

Submitted July 29, 2013 / Revised October 27, 2013, and February 3, 2014 /

Accepted February 10, 2014 / Published online July 23, 2014

Citation: Jemison, J. M., Jr., Hall, D., Welcomer, S., \& Haskell, J. (2014). How to communicate with farmers about climate change: Farmers' perceptions and adaptations to increasingly variable weather patterns in Maine (USA). Journal of Agriculture, Food Systems, and Community Development, 4(4), 57-70.

http://dx.doi.org/10.5304/jafscd.2014.044.001

Copyright (C) 2014 by New Leaf Associates, Inc.

\section{Abstract}

While dealing with weather variability has always been a source of stress for farmers, a generally warmer, wetter climate with the potential for increasingly intensive precipitation poses a threat to long-term farm viability. Knowing how farmers think about increasingly variable weather patterns (IVWP) is important for educators, agency staff,

a* Corresponding author: John M. Jemison Jr., 495 College Avenue; Orono, Maine 04473 USA; Jemison@maine.edu

${ }^{b}$ Damon M. Hall, Sustainability Solutions Initiative, The Margaret Chase Smith Center for Public Policy; University of Maine; 5784 York Complex \#4, Room 211; Orono, Maine 04469-5784 USA; damon.hall1@gmail.com

Damon Hall is now at the Center for Sustainability, Saint Louis University; Des Peres Hall, Suite 203E; 3694 West Pine Mall; St. Louis, Missouri 63108 USA; dmhall@slu.edu

c Stephanie Welcomer, Maine Business School, DPC Corbett Building, Room 315; University of Maine; Orono, Maine 04469 USA; Stephanie.welcomer@umit.maine.edu

d Jane Haskell, 5741 Libby Hall; University of Maine; Orono, Maine 04473 USA; Jane.haskell@maine.edu and others to learn how to work with producers on adaptation strategies to protect natural resources and prevent crop failure. In 2011, the University of Maine Cooperative Extension conducted focus group sessions with farmers from seven different commodity groups, five mixed farmer sessions, and two sessions with consultants, educators, and agency staff who work with growers to learn about grower perceptions of environmental changes, and to learn about changes they may be making to their farming operations to protect their operations from IVWP. Farmers discussed over 40 practices that could be construed as adaptation measures to buffer against IVWP. Fruit (apple and blueberry) growers spent the most time on the subject and expressed the most concern about the effects of IVWP, while dairy and potato growers spent the least. Given the divergence of opinion on the subject of climate change that Maine growers expressed, successful outreach education through the U.S. Department of Agriculture (USDA) and Cooperative Extension should likely emphasize short-term risk management, resilience, and 
stability of farm operations as opposed to communicating the need to adopt strategies based on climate change.

\section{Keywords}

adaptation, climate change, communication, farmers, global warming, production, sustainability

\section{Introduction}

The U.S. food system today is characterized by a highly energy-intensive production and distribution system, where most food travels an average of 1,500 miles $(2,414 \mathrm{~km})$ before reaching its destination (Halweil, 2002; Pirog, Van Pelt, Enshayan, \& Cook, 2001). The greenhouse gas emissions associated with agriculture and other human activities have been predicted to influence the climate by altering rainfall patterns, increasing the frequency of extreme weather, and increasing the length of the growing season in northern agricultural areas (Intergovernmental Panel on Climate Change [IPCC], 2007; Rosenzweig, 2000). With a nearly tenfold imbalance of energy input into food production relative to caloric output (Heller \& Keoleian, 2003), it is difficult not to concur with Borgmann (2011) that agriculture is accelerating climate change and that climate change is beginning to cause shifts and disruptions in agriculture. Yet results from a number of recent surveys of growers across the U.S. show that many farmers may believe that the climate is changing, but very few believe it is due to human activities (Morello, 2012). While this suggests that acceptance of climate change is not common among growers, these studies do not address growers' recognition of responses to new weather patterns. In this paper we assess growers' perceptions of changes in weather and their adaptations related to these changes. By examining growers' perceptions of weather as well as associated adaptations, we offer those who work with growers insights regarding strategies for enhancing the reach and impact of interventions. In this paper, the word "adaptation" is used to describe actions taken by farmers to protect soil resources from variable weather or climate change (Smit \& Skinner, 2002).

Several studies provide evidence that climate is affecting agricultural production in the Northeast
United States. Temperatures have increased in by over $1.8^{\circ} \mathrm{C}$ over the past 100 years Jacobson, Fernandez, Mayewski, \& Schmitt, 2009) and there has been a more than 70 percent increase in highprecipitation events (defined as $>1.0$ inches or $>2.5 \mathrm{~cm}$ in 48 hours) (Wake \& Markham, 2005). In some cases, such changes may represent possible opportunities to grow new crops, but extreme weather events such as tropical storm Irene in 2011 also show the risk to agricultural production and potential loss of soil due to erosion. In a recent publication, Hatfield et al. (2014) rated the likelihood as high that climate disruptions to agricultural production have increased in the recent past and are projected to increase further over the next 25 years. Variations in length of growing season, timing of frosts, heat accumulation, precipitation, evaporation, and soil moisture availability can influence production and producer and farming profit (Wall \& Smit, 2005).

Possible ways of addressing the risks posed by IVWP are to alter agricultural practices to mitigate greenhouse gas emissions associated with agriculture (Moreau, Moore, \& Mullinix, 2012a) (e.g., reducing tillage) and to adapt by lessening the underlying factors causing vulnerability to these phenomena (Schipper \& Pelling, 2006). While all agricultural production methods are vulnerable to climate variation to some degree, some commodities and production methods, particularly those with intensive tillage, are more susceptible to soil loss and yield variability. Agricultural adaptation strategies have been explored that potentially can reduce the impact of damaging weather on crop yield, soil loss, and water quality deterioration, such as (1) growing varieties with greater range of tolerance to heat stress and drought; (2) wider use of practices to conserve soil moisture, including reduced tillage; (3) altering timing and location of cropping activities; (4) diversifying farm income as much as possible; and (5) improving effectiveness of pest management by using more resistant varieties and improved weed management measures (Fraisse, Breuer, Zierden, \& Ingram, 2009; Howden, Sousanna, Tubiello, Chhetri, \& Dunlop, 2007). Other specific measures such as double-cropping small grains and corn have been shown to provide improved soil protection and 
increased forage production for dairy farmers by providing soil cover for a greater part of the year and more efficiently capturing and utilizing solar energy, compared to growing a full-season corn crop (Jemison, Darby, \& Reberg-Horton, 2012). If growers view these measures as beneficial and costeffective means to manage risk rather than treat them as adaptations to climate change, perhaps they will be more widely considered and could improve agricultural resilience.

While climate scientists are generally in agreement about the nature, causes, and consequences of climate change (Rosenberg, Vedlitz, Cowman, \& Zahran, 2010), a Rasmussen interview conducted in 2011 indicated that only a slight majority of Americans believe that climate change is a serious problem, and a vocal minority remains particularly hostile to climate scientists (Why don't Americans believe in global warming?, 2011). The issue is often polarized along partisan lines. So one should consider that many farmers may not think climate change is occurring, or might be offended by the concept or terminology associated with humaninduced climate change. While excellent methods have been proposed to educate farmers about what they can do to reduce greenhouse gas emissions associated with their production (Moreau et al., 2012b), farmers may not be receptive to learning about or adopting conservation practices if these are perceived to be related to climate change "fixes." Learning about minimizing risks related to volatile weather may be an avenue that engenders less grower resistance and more of their attention.

Learning what growers think about current weather patterns and their understanding of adaptation to mitigate effects of climate change is an important first step in preparing farmers to adopt strategies to protect soil and water resources from uncertain weather events. Some actions that growers could adopt, like cover cropping, reducing tillage, reducing on-farm energy use, and developing efficient local markets, are all sound and sustainable practices that farmers should adopt regardless of how they view the idea of climate change (Grubinger, 2009). Knowing how to conceptually approach growers and enhance their capacity to implement strategies to protect soil and water resources should be the basis of a core adaptation strategy (Meinke \& Stone, 2005).

This paper draws on a qualitative analysis of a cross-section of Maine's farmers who met in 2011 to discuss current and future farming issues. While the conversations covered a range of agricultural issues, this paper particularly focuses on Maine farmers' perceptions about weather variability and whether they were planning to or had implemented practices on their farms to reduce their risk of soil loss, crop failure, or related issues.

\section{Methods}

The purpose of the study was to assess farmers' and agricultural service providers' (ASP) thoughts about the future of Maine's agricultural industry. Because anticipating the future of a shared industry is a community matter, we chose to conduct focus groups to gather information from farmers and to promote discussion among the farmers (Brewer \& Gross, 2005). The program was called "Assessing Maine's Agricultural Future - 2025," and we actively recruited younger growers in an effort to focus on the future of farming in Maine. The sessions, however, were open to anyone interested in participating so as not to exclude relevant voices. We conducted group interviews with farmers from seven major agricultural commodities in the state, including potato, dairy, blueberry, vegetable, apple, beef, and the growers of nursery plants for the landscape industry (Table 1).

In addition, four sessions were conducted with farmers from across production groups (referred to in the quotations as MFG-1 through MFG-4), two sessions were held with crop advisors and university and agency staff who work closely with farmers, and one session was held with the staff of the Micmac Indian Nation who have a farm in northern Maine. Potential participants were identified with assistance from industry leaders, Extension educators working with specific commodities, or by recommendations from other growers. Participants are presented by age groups in Table 2 .

To encourage participation, interviews were conducted during the off-season across the state. When possible we coordinated sessions with previously scheduled grower events. Each session 
Table 1. Future of Agriculture in Maine - 2025 Focus Groups

\begin{tabular}{|c|c|c|c|c|}
\hline$\#$ & Location & Group & Date & $\begin{array}{l}\text { Participant } \\
\text { totals (female) }\end{array}$ \\
\hline 1. & Orono, Maine & Mixed farmer group (MFG) \#1 & 10 Dec 2010 & $11(7)$ \\
\hline 2. & Augusta, Maine & Mixed farmer group (MFG) \#2 & 12 Jan 2011 & $12(5)$ \\
\hline 3. & Portsmouth, New Hampshire & Agricultural Service Providers (ASP) - \#1* & 26 Jan 2011 & $24(6)$ \\
\hline$\overline{4 .}$ & Portsmouth, New Hampshire & Agricultural Service Providers (ASP) - \#2* & 26 Jan 2011 & $23(2)$ \\
\hline 5. & Belfast, Maine & Mixed farmer group (MFG) \#3 & 28 Jan 2011 & $26(16)$ \\
\hline 6. & Presque Isle, Maine & Micmac Indian Nation & 2 Feb 2011 & $4(1)$ \\
\hline 7. & Presque Isle, Maine & Potato growers & 2 Feb 2011 & $11(1)$ \\
\hline 8. & Ellsworth, Maine & Blueberry growers & 9 Feb 2011 & $10(3)$ \\
\hline 9. & Augusta, Maine & Vegetable growers & 25 Feb 2011 & $6(0)$ \\
\hline 10. & Unity, Maine & Dairy producers & 2 March 2011 & $15(4)$ \\
\hline 11. & Unity, Maine & Organic growers-mixed farmer group (MFG) \#4 & 16 March 2011 & $14(5)$ \\
\hline 12. & Presque Isle, Maine & Vegetable growers & 30 March 2011 & $5(2)$ \\
\hline 13. & Presque Isle, Maine & Beef producers & 30 March 2011 & $17(2)$ \\
\hline 14. & Monmouth, Maine & Apple producers & 14 April 2011 & $11(1)$ \\
\hline \multirow[t]{2}{*}{15.} & Manchester, Maine & $\begin{array}{l}\text { Horticultural growers (Maine Landscape and } \\
\text { Nursery Association [MELNA]) }\end{array}$ & 13 July 2011 & $10(1)$ \\
\hline & Totals & & & $199(56)$ \\
\hline
\end{tabular}

*Agricultural Service Provider Sessions (ASP) were divided into two groups: Session 1 included primarily Extension Educators and Natural Resource Conservation Service staff; session 2 included primarily private crop consultants who work directly with farmers. Based on field notes headcounts.

178 filled out demographic information forms.

lasted between 90 and 120 minutes. We asked participants 10 questions (Table 3).

Audio from the sessions was digitally recorded, transcribed, and analyzed using QSR NVivo 9 qualitative analytic software. Thematic categories were established based on interview questions, and participant comments were coded as positive, negative, or "action taken." For example, if a grower said that winters were definitely warmer and this allowed planting a new crop, this would have been coded as a positive perception of climate change, and the change in crop would have been

Table 2. Program Attendees by Age Group Who Participated in the “Assessing Maine's Agricultural Future - 2025" Program, 2011

\begin{tabular}{lrrccc}
\hline Participants & Numbers* & \multicolumn{4}{c}{ Age Distribution (years) } \\
\hline & & $<\mathbf{3 0}$ & $\mathbf{3 0 - 3 9}$ & $\mathbf{4 0 - 4 9}$ & $>\mathbf{5 0}$ \\
\hline Farmers & 135 & 37 & 26 & 25 & 47 \\
\hline Crop Advisors & 43 & 2 & 8 & 12 & 21 \\
\hline Total & 178 & 39 & 34 & 37 & 68 \\
\hline
\end{tabular}

* An additional 21 individuals participated as determined by counting participants in the room, but they did not fill out demographic information forms. tracked as an action taken. With the software, group similarity associations were made based on Pearson correlations of language and topics raised by participants in the commodity and mixed farmer sessions. We present the results of these focus groups regarding changes farmers are making related to variable weather patterns along with a spectrum of the verbatim responses made by farmers concerning their perceptions of the predictability of weather and climate change. The quotations are included to capture the language growers use to discuss these issues and reflect the diversity within and between farming groups. Because this analysis was made at the group level, we did not analyze language at the level of individuals, and therefore we did not track comments made by specific growers within a group. 


\section{Table 3. Questions Asked of All Focus Group Participants}

1. Why did you choose agriculture for your profession?

2. What were some of the first words or thoughts that came to mind when you heard about this focus group for "Assessing Maine's Agricultural Future - 2025" and beyond? Or what led you to choose to participate in this session?

3. What is going well for Maine agriculture and what are you optimistic about for the future?

4. What concerns you about the future?

5. What changes are you making on your farm relative to recent weather patterns?

6. What changes are you making on your farm relative to volatile energy pricing?

7. What can the state do to grow agriculture?

8. How are you getting information today related to your industry?

9. What will Maine agriculture look like in 2025 ?

10. What questions should we have asked that we didn't?

\section{Results}

A total of 199 people participated in this project. Demographic forms were completed by 178 participants (Table 1). Of the 178 forms collected, 58 participants were female. When growers were asked what they were optimistic about, the most common responses were the public's growing interest in local foods, the availability of affordable land and water to farm, and the large potential markets within a day's drive of Maine. When asked what they were concerned or pessimistic about, growers focused primarily on issues of regulations and rising energy costs. Issues like the growing size of farms and the loss of support and infrastructure were also mentioned. Before being asked specifically about changing weather patterns, only one grower commented that he was concerned about the lack of predictable weather.

That no other grower expressed concern about apparently IVWP, without being prompted, was somewhat surprising. Variability is a characteristic of weather, but since farmer livelihood is dependent on weather and given the increased precipitation frequency and intensity reported in New England (Hayhoe et al., 2007), we expected that more farmers would mention it as a source of concern. Further, the majority of these interviews were conducted from December 2010 through April 2011, following two widely variable growing seasons: The summer of 2009 was one of the wettest summers on record (Stampone, 2010). This was followed by an extremely warm winter and early spring in 2010. Many fruit growers lost much of their crop due to late frosts that killed flowers that opened earlier than normal due to an early bud break. Yet only one grower, before being prompted by a question specific to weather, mentioned changing climate as a source of concern.

While growers did not initially or spontaneously express concern about current weather patterns, there was considerably more discussion when farmers were asked what changes they were making on their farm with respect to fluctuating or variable weather patterns. We specifically chose not to use the term "climate change" because of the politicized nature of the term (Pielke, 2010), and we also wanted to hear what terms Maine farmers used to describe their experience with local weather patterns. However, several growers considered the question as a prompt to talk about climate change and expressed their opinions on the topic; below are a few statements that reflect dissent or disagreement that climate change is occurring:

- 'It always seemed like it's been like this. I can't remember really fantastic springs. Every year is different. I really don't think that we've seen a change." (beef producer)

- "[The] climate is changing all the time." (dairy farmer)

- "I don't think that the weather patterns of Maine have changed significantly..." 
(blueberry grower)

- "What is 200 years in the realm of the earth? We don't have a clue what's going on." (beef producer)

- "Just in the last two years we've gone through one of the wettest years in history to one of the driest. So how can you call that a pattern? I've certainly been through wet and dry and that's just what it is." (dairy producer)

- "If they say that the climate is changing due to, what's the big word? Global warming. If this is global warming, I love every minute of it." (beef producer)

In contrast, other farmers, particularly apple and blueberry growers, expressed real concern that environmental conditions were changing. For example, one apple grower who had saved his records of pesticide applications for over 20 years found he was spraying significantly earlier in the season. Examples of these statements include:

- “There's no denying it. There is now a five to ten day earlier need to get out in the field. I mean, that's telling you something about the climate." (apple grower)

- "I do believe global warming is going to have a very severe impact on the blueberry industry even with irrigation because the heat in August has become so intense that it can literally cook the berries within hours in the field. So, I do think that that environmental aspect of global warming is something we're going to be dealing with in 20 or 30 years." (blueberry grower)

- "Yeah, the winters aren't quite as cold but the erratic weather's a problem. I agree... a problem for agriculture is the up and down swing." (apple grower)

- "The climate of Maine provides a competitive advantage for producing crops that other climates cannot produce. Changing climate threatens the stability of this certainty." (blueberry grower)

- "The problem with weather and growing food is that the climate in which we grow food, well there's a very narrow window of stability. I mean, we get outside that window very far and everything falls apart. So yeah, I mean it's a real serious concern." (blueberry grower)

- “There's still a lot of resistance to climate change, and there's still a lot of people think it's a hoax. But, I'm concerned about McIntosh [apples] requiring a very specific weather. And if that changes, our major crop is going to be dramatically affected. That apple has to compete on the shelf and so far we've been able to produce a good product and compete with the Fujis and the Braeburns and those other varieties that we can't grow. If we can't grow a quality McIntosh people aren't going to buy it...Providing the weather stays the same, it's a variety that we can do here that nobody else can do well." (apple grower)

- "Back to back, with these weather changes you saw probably our toughest year two years ago, the best growing year last year and when you start getting a hundred year storms every four years, you begin to wonder, you know, that perhaps there is something to this sort of thing." (apple grower)

Other related grower and consultant comments are presented below:

- 'I think we've experienced a warming trend, which isn't necessarily bothersome to most of us because we're in a pretty cold climate to start with. But, I don't know where that's going to end." (beef producer)

- "They're [farmers] not thinking that...the climate is getting warmer and warmer, it's that it's getting more unpredictable, with greater extremes, and shorter intervals between those extremes. You know, they need to understand that it's not necessarily an opportunity, but they need to have some flexibility in there or be aware of what those changes are to keep those in mind for their long term plans." (ASP \#2) 
Some growers expressed optimistic views about Maine climatic conditions:

- "We have relatively stable climate compared to a lot of areas and I think that's the big thing." (vegetable grower)

- "But the realistic thing is that Maine does have four real seasons and we do have some protection because we're close to the coast. If there is global warming, then I don't think it's going to affect us as much as say, Arizona or California." (blueberry grower)

These suggest that growers' attitudes about climate change are mixed, ranging from dissent to acceptance, and beyond acceptance to welcoming it. This mixed level of acknowledgment and concern, however, is not the same for outcomes associated with changing weather, such as new pests and increasingly extreme and erratic weather.

New pests are an issue that agricultural publications and Cooperative Extension staff cover in educational programming. Apparent concern about this issue appeared to be greater for vegetable growers and consultants than for growers of other commodities:

- "It seems as if, what has been considered the norm for the recent past is changing and new insects and new diseases have showed up in my brief period of time being here and, granted, that's always been happening, but I guess it was disconcerting for everyone that it ever happened to. It makes you wonder what the future is going to bring in terms of new weather patterns, new diseases, and new insects. And it's just interesting when you can actually see it happen. When I first moved to Maine in 1996 there were no Japanese beetles in [town name]. Now there are Japanese beetles." (vegetable grower)

- "We're seeing more insects problems than I've seen in the last three or four years. We've seen striped cucumber beetles, squash bugs, more Colorado potato beetles. I'm just seeing more bugs than
I've seen [before] and cause of the cli - it is warmer. Ha, I mean sorry, it is warmer." (vegetable grower)

- "The other negative thing that I've noticed is a lot of the real scary pests that live down south have started to rise [agreement from crowd] because our winters are so bad that they usually kill them. But, not so much [in recent years]." (grower: MFG \#2)

- "In Vermont, a lot of the farmers that I am working with have recognized that the climate is changing and that it's different. Anybody with a close relationship to the land knows that we're seeing a lot of differences from diseases to pests that we've never seen before. We've never had ticks in northern Vermont. We've never had certain diseases, and people that are really in tune with the land realize there is something going on, but I would agree people aren't saying oh, it's global warming. They just know that the weather has changed.... Things are changing, and I don't think that our farmers are looking at as, oh, it's just that year. They know that things are changing. So, we're trying to adapt to that." (ASP \#2)

Not surprisingly for people who rely on weather to make a living, several famers spoke about always having to fight the vagaries of weather. We were specifically interested in hearing how farmers discussed variable weather:

- "It's really not a gradual transition that you used to be able to read and figure out. And it's chaotic....It's really a tricky thing and I think people should be talking about it." (organic farmer, MFG \#4)

- "You have to believe that build-up of carbon dioxide has some sort of effect on that [weather], and we, as farmers, can have some influence on that. You know, we can sequester carbon back into the soil and help with that. We can help ourselves at the same time." (beef producer)

- "The perception that weather is warming and becoming more moderate is a public 
misunderstanding, it is becoming more erratic." (grower, MFG \#3)

- "There is some documentation that says since the 1940s, lilacs are blooming two weeks earlier. There is absolutely no question that it affects plants greatly in the way that they behave. If last year told us anything it's that getting an early start on growth is not necessarily a good thing because when we had seventeen degrees in the middle of May, it toasted every single hydrangea, magnolia, anything with longer than two inches of new growth was dead the next morning. Then it happened the next night, as well. Plants cannot adapt to that. If it is too warm for too long like it was a year ago, there is no question that it cost us all thousands of dollars....If overall we said all right, the weather is moderating, we're going to be able to grow more things. People laugh that we'll be growing oranges and bananas. Well, no, we won't..." (landscape and nursery association grower)

- 'You're all talking about some pretty consistent weather changes, I think, and there's probably a lot to that. I've had a bigger problem with it being just unpredictable. And, the only thing I can really think to do about this is to diversify and hopefully if one thing doesn't do too well another thing does." (grower, MFG \#2)

Descriptions of the impacts caused by weather extremes:

- "Irrigation helps, but you can still lose; we've lost an entire crop in two days due to heat stress. Forty acres, gone.... I mean, it can happen within hours." (blueberry grower)

- "Any time that you have to deal with extreme, either extreme wet or extreme drought, there is a whole different level of environmental issues that come into play. When they have a drought year in Aroostook County, everybody's drawing water for irrigation out of Caribou Lake. And, they pretty much drain it.” (ASP \#2)
Although growers were mixed in their assessment of the existence and in their concerns about climate change, they articulated common concerns about factors associated with weather changes such as more erratic weather, new pests and more extreme weather events. Although the cause of these factors was in dispute, the issues themselves were largely common across grower groups. Prominent in growers' responses were the importance of managing for weather, as well as attendant strategies to address specific perceived threats such as new pests and uncertain and extreme weather.

\section{Issues in Managing for V ariable Weather}

Unable to control the inevitable vagaries of nature, growers spoke about possible efforts to improve farm management so as to hedge against vagaries of climate. Example quotations are provided below:

- "What do we do? I order an extra pallet of plastic so I can put up more silage if it's a real rainy year. If it's a dry year, we make dry hay. It's all we can do. You ain't gonna change the weather." (beef producer)

- "There's never been two seasons alike it's how you manage that [season's] weather that is important." (dairy producer)

- "We make changes all the time to adapt to whatever the situation is. I mean, to try to anticipate that this next year is going to be like last year it [is] just, just a waste [of] time....In the end I gotta have a crop to feed my cows and I'm not trying to anticipate that next year I'm going to be able to be in the field on the 15th. I'm going to be ready to be in the field on the 15th but if it doesn't work that way we'll get there somehow." (dairy producer)

- "I think the biggest thing the weather patterns have done for me is learning how to stay on top of my management." (vegetable grower)

- "Some growers are trying to increase their land base, so they can go to longer rotations to counteract some of the dry weather we've been experiencing." (ASP \#2)

- "Be nimble is all I can say." (apple grower) 
- 'Yes, that's a good way of putting it, you've got to be ready." (apple grower)

- "Mother nature's a bitch....Deal with it." (apple grower)

- 'I've seen some stuff from over in Europe where they were playing with hail cannons and they sent something about the size of a silo that they blew up to try to split a thunderstorm in half." (apple grower)

- "I think resilience is a great concept to keep in mind if you're involved in agriculture and just that idea of being able to withstand challenges whether they're economic or weather." (blueberry grower)

These quotations illustrate growers' apparent understanding of the need to be knowledgeable and responsive to issues associated with IVWP in modern farming. Strategies to respond include specific measures such as water management, season extension, and systemic approaches using ecological methods and farm diversification.

\section{Diversifying Operations}

- "The only thing I can really think to do about this is to diversify and hopefully if one thing doesn't do too well another thing does." (vegetable grower)

- "But I think for most people, the best hedge against that unpredictability is diversity." (organic grower: MFG \#4)

\section{Adding Irrigation and/ or Tile Drainage}

- "In Aroostook County irrigation is becoming a big thing now. There are irrigation units going in every year now and ponds are being made. Our weather hasn't been very predictable; we've had dry summers, two or three in a row. It's affected the yield, so we're getting a lot more irrigation up there." (ASP \#1)

- "We have added irrigation also and that's something that was never, we never thought we'd need, but we have added irrigation." (grower, MFG \#1)

- "There is more tile draining, there's kind of a Renaissance going on. I thought it kind of slowed up in the '60s and '80s, now guys are realizing that six inches of raining can be handled.” (vegetable grower)

\section{Extending the Season}

- 'We hope to extend the season. It's a short season up here. Extend it with the green houses, and also high tunnels." (Micmac)

\section{Adopting More Ecological Production Methods}

- "It seems to me is what's happening is the trend isn't a trend anymore; it's just totally unpredictable. Or we're trending more towards unpredictability. And I think that's consistent with the scientific models that are predicting climate change. And I think that most people here understand that intuitively and use diversity as a tool, not necessarily to hedge against that climate change but it happens to have multiple benefits. I mean, this is an ecological principle, right. There's so many benefits of diversity, and this is just one of them... All the long-term ecological studies that are comparing sort of conventional soil management with organic for lack of a better word, ecological, really show that ecological soil management is really much less vulnerable to climate variability and unpredictability for various reason. So I think that's really the best hedge that all of us can have. And aside from that just investing in other ways to control the things that you need." (organic grower, MFG \#4)

- "We need to help farmers build more resilient systems because there are these extremes, and they're very difficult to deal with if a farmer is not prepared. And, I am talking about like whole system changes to crop rotations and just different things like that. Once farmers start doing it, I found that they realize, 'Oh, my soil drained better this year because I am not growing continuous corn anymore and going through a quicker rotation. So, then when I got ten inches of rain, my soil didn't become a compacted pancake.' Our job is to help guide them [to] build a more resilient system, and in some cases, it's not what they're used to, so we have to really be up on our game thinking of different things to do.” (ASP \#2) 
The quotations above provide a sense of the language growers used describing variable weather and measures taken to adapt to it. Growers' comments were also quantified to assess how easy it might be to get growers to adapt practices to protect their farm assets from IVWP. Twenty grower comments were coded as suggesting specifically negative impacts (generally not positive to growth or economic viability) of a changing climate, compared to only seven comments suggesting positive impacts (Table 4).

The negative comments mostly reflected a fear of new pests (diseases and invasive species) and general lack of control of weather (such as the growing costs associated with adaptation strategies of hoop houses and transitioning to irrigation equipment used on vegetable farms today). Positive comments included the potential opportunities created by longer or extended seasons and the possibility of growing new crops.

\section{Discussion}

Variable weather patterns have always and will continue to play an important role in the production risks faced by farmers (Adams, Hurd, Lenhart, \& Leary, 1998; Fraisse, Breuer, Zierden and Ingram, 2009). How farmers view IVWP or climate change and whether they may be implementing measures to adapt to this have not been fully explored, particularly among U.S. farmers. Recent studies have evaluated farmer vulnerability and willingness to adopt specific farming practices to adapt to climate change in the Sahel and in Burkina Faso, areas prone to wide fluctuations in weather (Barbier, Yacouba, Karambiri, Zoromé, \& Somé, 2009; Mertz, Mbow, Reenberg, \& Diouf, 2009; Ogalleh, Vogel, \& Houser, 2013). Growers have adopted strategies like crop diversification, variety selection, and micro water harvesting, but in both places, researchers could not specifically report that the adaptations were implemented because of concern over climatic impact on production. More often profit or greater food security was the reason given for the management change. Growers in the U.S. have been privileged to have many more tools available to protect them from variable weather, including crop insurance, irrigation and drainage, and now a wider variety and selection of hybrid options, including transgenic drought-tolerant lines.

Growers' responses indicate that, as supported by previous studies, there is a mixture of opinions about linking weather changes explicitly to climate change. There is, however, awareness and recognition of changes to weather and in outcomes related to these changing weather patterns. Growers say that seasons are shifting, new pests are appearing, variability is the "new normal," and managing water in both drought and flood conditions is a priority.

Most of the growers interviewed in this study seemed to stress that weather was becoming increasingly variable, but whether most viewed this as an indicator of a changing climate was not clear. A majority viewed IVWP as negative to farm productivity (Table 4). This is in contrast to a study
Table 4. Negative and Positive Comments Related to Fluctuating Weather Patterns or a Warming Climate

\begin{tabular}{ll}
\hline \multicolumn{1}{c}{ Negative Comments } \\
\hline $\begin{array}{l}\text { Grower Group } \\
\text { Apple }\end{array}$ & Observation (\# of mentions) \\
Petato & More pest pressure (6) \\
\hline $\begin{array}{l}\text { Apple } \\
\text { Blueberry }\end{array}$ & More crop damage (5) \\
\hline Apple & Too erratic (4); lack of rain (3); lack of snow protection (2) \\
Blueberry & \\
MELNA & \\
Beef & \\
Dairy &
\end{tabular}

\begin{tabular}{ll}
\hline & \multicolumn{1}{c}{ Positive Comments } \\
\hline Grower Group & Observation (\# of mentions) \\
\hline Vegetable & Earlier sweet corn to market \\
\hline Apple & New crop potential, specifically peaches and cherries \\
\hline $\begin{array}{l}\text { Potato } \\
\text { Dairy }\end{array}$ & Longer growing season (4) \\
Vegetable & \\
\hline Beef producers & Earlier grazing potential
\end{tabular}


done with growers in the UK, where Holloway and Ilbery (1996) found that growers viewed global warming from a slightly more positive than negative perspective, specifically due to the possibility of growing different crops and gaining higher yields of maize and small grain cereals. They also found that the participating UK farmers were more concerned about specific environmental issues or regulations that were imposed upon them rather than climatic change. In some cases, we found similar results; some potato farmers expressed hope that a longer growing season would boost yields. While we didn't ask growers to rate concern over regulations compared to concern over variable weather, we found that when we asked farmers to discuss policy changes they felt were needed at the state level, they had more specific comments about reducing regulations than they did for specific policy measures that might help farmers facing IVWP and a less predictable crop production environment.

Adams et al. (1998) reported that rates and levels of adaptation depend on the risk preferences of farmers. Subsistence farmers are more likely to

\section{Table 5. Specific Management Measures Implemented Due to Fluctuating Weather Patterns or a Warming Climate}

\begin{tabular}{ll}
\hline Specific Management Measures (\# of mentions) & Grower Group \\
\hline Increased reliance on hoop houses for environmental control (5) & Vegetable \\
Drainage tiles (4) & \\
Fewer cold-hearty varieties & \\
More hoop houses (5) & \\
Use of permanent mulch systems & \\
Irrigation (4) & \\
Raised beds (4) & \\
Increasing diversity beyond vegetables & \\
Planting earlier sweet corn & Apple \\
Extending our season & \\
Permanent mulch & \\
\hline Use of hail nets (2) & Potato \\
Irrigation (3) & Beef producers \\
Planting more peaches and cherries & \\
\hline Growing longer varieties & Blueberry \\
\hline Earlier grazing & Landscape \\
Plastic-wrapped silage & \\
\hline Irrigation & \\
\hline Irrigation & \\
Drainage & \\
More hearty and/or locally adapted varieties & \\
\hline
\end{tabular}

diversify their planting based on their need to survive. In contrast, technologically driven farming systems may be more susceptible to loss as they generally consist of larger acreage of one or two major crops. Interestingly, the dairy and potato commodity farmers (generally larger acreage farms relative to farms typical of the producers in the mixed farmer sessions) spent less time on the topic of IVWP than most of the smaller acreage growers, and these growers' comments were grouped similarly in the NVivo analysis. Potato production involves many tools or practices that inherently help those growers protect themselves from variable weather (seed treatments, fungicide use, irrigation, etc.). Potato growers are dependent on intensive tillage, and soil loss is a particular threat with IVWP particularly when soil is exposed (after planting and after harvest). Many dairy farmers can reduce tillage and can usually grow more corn affordably and harvest more hay acreage than they need to protect them from environmental variability. Further, dairy farmer concerns are divided between crop production and animal health and milk production, and as such, they may focus somewhat less on issues of IVWP than fruit or vegetable producers. NVivo also grouped the blueberry and apple growers and the beef producers together in one group, in part based on the number of comments and word associations made in discussing IVWP.

Participating growers mentioned at least 41 different practices that could be considered examples of adaptation that they had implemented on their farms (Table 5).

This is not an exhaustive list of all the practices these farmers might have implemented because it is possible that if one participant were to mention a method or practice, another participant may choose not to raise the same point. Also, decisions to implement 
these practices to reduce risk have to be considered in the context of a wide range of other reasons: increased yield, earliness of harvest, disease prevention, etc. However, considering that we heard growers mention at least 41 adaptation practices implemented on their farms, we considered this to be positive.

While these data show the rich variability in grower responses to issues of IVWP, they also raise the question of how agricultural service providers (consultants, educators, and agency staff) should approach growers to encourage them to implement more adaptive measures. Howden et al. (2007) suggest several possible solutions: reward early adopters; focus educational programs on climate risk management; research effectiveness of adaptation strategies; and better understanding adoption rates and how to improve them. Quantifying potential benefits of adoption strategies and having earlyadopter farmers discuss changes seen on their farms in educational programs should help increase the pace of adoption.

Outreach programs through USDA and Cooperative Extension should emphasize resilience and stability of farm operations as opposed to communicating the need to adopt strategies based on climate change. As Howden et al. (2007) state, “'adaptation' is an ongoing process that is part of good risk management" (p. 19692), and the more that extension and agricultural consultants move farmers in this direction, the better positioned the grower should be. Further, programs should motivate growers to adapt solutions that emphasize increasing resilience rather than attempting to motivate based on articulation of climate change. Based on how Maine farmers discussed the issues, we believe most other farmers will be receptive to programs that fit a culture of problem solving and reducing risk. Salient problems identified by Maine growers were erratic and/or extreme weather and new pests. These issues potentially could be productive entry points for agriculture consultants to use when discussing key adaptive strategies to handle threats. Consultants could also pursue or capitalize on perceived opportunities vis-à-vis discussing new crops and season-extension measures.

\section{Conclusions}

If predictions from groups like the Northeast Climate Impact Assessment are correct, winter and summer temperatures will rise, more winter precipitation will fall in the form of rain, and the intensity of storms will increase regardless of changes made in energy emissions (Frumhoff, McCarthy, Melillo, Moser, \& Wuebbles, 2007; Wolfe, 2005). A warmer atmosphere will likely hold more moisture, and precipitation frequency, amounts, and intensity will increase (Frumhoff et al., 2007). Given this, there is an increasing sense of urgency to engage farmers in discussions about adaptation strategies to protect long-term farm income, build soil health, and protect natural resources (Moreau et al., 2012a). Focus group discussions are an excellent means to respectfully learn how growers perceive changes and to assess growers' inclination to implement changes on their farm to protect long-term farm viability and do their part to protect natural resources.

\section{Acknowledgments}

We acknowledge the time and help our participating growers gave to this work. This material is based upon work supported by a Trustee Professorship from the University of Maine and the National Science Foundation under award \# EPS0904155.

\section{References}

Adams, R. M., Hurd, B. H., Lenhart, S., \& Leary, N. (1998). Effects of global climate change on agriculture: An interpretative review. Climate Research, 11(1), 19-30. http://dx.doi.org/10.3354/cr011019

Barbier, B., Yacouba, H., Karambiri, H., Zoromé, M., \& Somé, B. (2009). Human vulnerability to climatic variation in the Sahel: Farmers' adaptation strategies in Northern Burkina Faso. Environmental Management, 43(5), 790-803. http://dx.doi.org/10.1007/s00267008-9237-9

Borgmann, A. (2011, June). The culture of the table: Reweaving the contexts of celebration. Speech presented at the annual meetings of the Agriculture, Food, and Human Values Society (AFHVS), Association for the Study of Food and Society (ASFS), and Society for Anthropology of Food and Nutrition conference, Missoula, Montana. 
Brewer, P. R., \& Gross, K. (2005). Values, framing, and citizens' thoughts about policy issues: Effects on content and quality. Political Psychology, 26(6), 929948. http://dx.doi.org/10.1111/j.14679221.2005.00451.x

Fraisse, C. W., Breuer, N. E., Zierden, D., \& Ingram, K. T. (2009). From climate variability to climate change: Challenges and opportunities to Extension. Journal of Extension, 47(2), 2FEA9. http://www.joe.org/joe/2009april/a9.php

Frumhoff, P. C., McCarthy, J. J., Melillo, J. M., Moser, S. C., \& Wuebbles, D. J. (2007). Confronting climate change in the U.S. Northeast: Science, impacts, and solutions. Synthesis report of the Northeast Climate Impacts Assessment (NECIA). Cambridge, Massachusetts: Union of Concerned Scientists. Retrieved from http://www.northeastclimateimpacts.org/

Grubinger, V. (2005). Climate change and agriculture: Challenges and opportunities for outreach. Brattleboro, Vermont: University of Vermont Extension, Center for Sustainable Agriculture.

Halweil, B. (2002). Home grown: The case for local food in a global market (Worldwatch Paper No. 163). Washington, D.C.: Worldwatch Institute. Retrieved from http://www.worldwatch.org/node/827

Hatfield, J., Takle, G., Grotjahn, R., Holden, P., Izaurralde, R. C., Mader, T., Marshall, E., \& Liverman, D. (2014). Agriculture. In J. M. Melillo, T. C. Richmond, \& G. W. Yohe (Eds.), Climate Change Impacts in the United States: The Third National Climate Assessment (pp. 150-174). Washington, D.C.: U.S. Global Change Research Program. http://dx.doi.org/10.7930/J0Z31WJ2

Hayhoe, K., Wake, C. P., Huntington, T. G., Luo, L., Schwarz, M. D., Sheffield, J.,...Wolfe, D. (2007). Past and future changes in climate and hydrological indicators in the US Northeast. Climate Dynamics, 28(4), 381-407. http://dx.doi.org/10.1007/s00382$\underline{006-0187-8}$

Heller, M. C., \& Keoleian, G. A. (2003). Assessing the sustainability of the US food system: A life cycle perspective. Agricultural Systems, 76(3), 1007-1041. http://dx.doi.org/10.1016/S0308-521X(02)00027$\underline{6}$

Holloway, L. E., \& Ilbery, B. W. (1996). Farmers' attitudes towards environmental change, particularly global warming and the adjustment of crop mix and farm management. Applied Geography, 16(2), 159-171. http://dx.doi.org/10.1016/01436228(95)00034-8

Howden, S. M., Sousanna, J.-F., Tubiello, F. N., Chhetri, N., Dunlop, M., \& Meinke, H. (2007). Adapting agriculture to climate change. Proceedings of the National. Academy of. Science, 104(50), 19691-19696. http://dx.doi.org/10.1073/pnas.0701890104

Intergovernmental Panel on Climate Change [PCC]. (2007). Climate Change 2007 _ Impacts, adaptation and vulnerability: Working Group II contribution to the Fourth Assessment Report of the IPCC. Cambridge, UK, and New York: Cambridge University Press.

Jacobson, G. L., Fernandez, I. J., Mayewski, P. A., \& Schmitt, C. V. (Eds.). (2009). Maine's climate future: An initial assessment. Orono, Maine: University of Maine. http://www.climatechange.umaine.edu/ mainesclimatefuture/

Jemison, J. M., Darby, H. M., \& Reberg-Horton, S. C. (2012). Winter grain-short season corn double crop forage production for New England. Agronomy Journal, 104(2), 256-264. http://dx.doi.org/10.2134/agronj2011.0275

Meinke, H., \& Stone, R. C. (2005). Seasonal and interannual climate forecasting: The new tool for increasing preparedness to climate variability and change in agricultural planning and operations. Climatic Change, 70(1-2), 221-253. http://dx.doi.org/10.1007/s10584-005-5948-6

Mertz, O., Mbow, C., Reenberg, A., \& Diouf, A. (2009). Farmers' perceptions of climate change and agricultural adaptation in rural Sahel. Environmental Management, 43(5), 804-816. http://dx.doi.org/10.1007/s00267-008-9197-0

Moreau, T. L., Moore, J., \& Mullinix, K. (2012a). Mitigating agricultural greenhouse gas emissions: A review of scientific information for food system planning. Journal of Agriculture, Food Systems, and Community Development, 2(2), 237-246. http://dx.doi.org/10.5304/jafscd.2012.022.007

Moreau, T. L., Moore, J., \& Mullinix, K. (2012b). Planning for climate action in British Colombia, Canada: Putting agricultural greenhouse gas mitigation on local government agendas. Journal of Agriculture, Food Systems, and Community Development, 2(2), 247-259.

http://dx.doi.org/10.5304/jafscd.2012.022.008 
Morello, L. (2012, October 5). Most farmers see climate change but can't see humans causing it. E\&E Publishing. Retrieved from http://eenews.net/ public/climatewire/2012/10/05/1

Ogalleh, S. A., Vogel, C., \& Houser, M. (2013). Reading from farmers' scripts: Local perceptions of climate variability and adaptations in Laikipia, Rift Valley, Kenya. Journal of Agriculture, Food Systems, and Community Development, 3(2), 77-94, http://dx.doi.org/10.5304/jafscd.2013.032.004

Pielke, R., Jr., (2010). The climate fix: What scientists and politicians won't tell you about global warming. New York: Basic Books.

Pirog, R., Van Pelt, T., Enshayan, K., \& Cook, E. (2001). Food, fuel, and freeways: An Iowa perspective on how far food travels, fuel usage, and greenhouse gas emissions. Ames, Iowa: Leopold Center for Sustainable Agriculture. Retrieved from http://www.leopold.iastate.edu/sites/default/files/ pubs-and-papers/2011-06-food-fuel-and-freewaysiowa-perspective-how-far-food-travels-fuel-usageand-greenhouse-gas-emissions.pdf

Rosenberg, S., Vedlitz, A., Cowman, D. F., \& Zahran, S. (2010). Climate change: A profile of US climate scientists' perspectives. Climatic Change, 101(3-4), 311-329. http://dx.doi.org/10.1007/s10584-0099709-9

Rosenzweig, C., (2000). Potential impacts of climate change on agriculture. In American Society of Agronomy, Crop Science Society of America, and Soil Science Society of America, A spectrum of achievement in agronomy: Women fellows of the Tri-Societies (ASA Special Publication No. 62) (pp. 73-88). Retrieved from http://pubs.giss.nasa.gov/abs/ro07100z.html
Schipper, L., \& Pelling, M. (2006). Disaster risk, climate change and international development: Scope for, and challenges to, integration. Disaster, 30(1), 19-38. http://dx.doi.org/10.1111/j.1467-9523.2006. 00304.x

Smit, B. \& Skinner, M. W. (2002). Adaptation options in agriculture to climate change: A typology. Mitigation and Adaptation Strategies for Global Change, 7(1), 85114. http://dx.doi.org/10.1023/A:1015862228270

Stampone, M. D. (2010). New Hampshire seasonal climate summary. New Hampshire Seasonal Climate Summary, 1(1). Retrieved from http://www.unh.edu/stateclimatologist/

Clean Air-Cool Planet \& Wake, C. P. (2005). Indicators of climate change in the Northeast 2005. Portsmouth, New Hampshire, and New Canaan, Connecticut: Clean Air-Cool Planet. Retrieved from http://www..epa.gov/region1/eco/energy/pdfs/ IndicatorsClimateChangeNortheast2005.pdf

Wall, E., \& Smit, B. (2005). Climate change adaptation in light of sustainable agriculture. Journal of Sustainable Agriculture, 27(1), 113-123. http://dx.doi.org/10.1300/J064v27n01 07

Why don't Americans believe in global warming? [Web log posting]. (2011, February 8). The Economist. http://www.economist.com/blogs/democracy inamerica/2011/02/climate change

Wolfe, D. W. (2005). Climate change impacts on northeast agriculture: Overview. Ithaca, New York: Cornell University. Retrieved from the Maine Food Strategy website: http://mainefoodplan.files.word press.com/2014/01/climate-change-impacts-onnortheast-ag-overview.pdf 